\title{
Adjusting the growth curve of sugarcane varieties using nonlinear models
}

\author{
Sérgio Alberto Jane ${ }^{1,2}$ (iD) Felipe Augusto Fernandes ${ }^{2}$ (D) Edilson Marcelino Silva ${ }^{2}$ iD \\ Joel Augusto Muniz $^{3 *}$ (D) Tales Jesus Fernandes ${ }^{3}$ (D) Guilherme Vieira Pimentel ${ }^{4}$ (D)
}

${ }^{1}$ Faculdade de Ciências Agrárias, Universidade Lúrio (UniLúrio), Nampula, Moçambique.

${ }^{2}$ Programa de Pós-graduação em Estatística e Experimentação Agropecuária, Departamento de Estatística (DES), Universidade Federal de Lavras (UFLA), Lavras, MG, Brasil.

${ }^{3}$ Departamento de Estatística (DES), Universidade Federal de Lavras (UFLA), 37200-000, Lavras, MG, Brasil. E-mail: joamuniz@ufla.br. ${ }^{*}$ Corresponding Author

${ }^{4}$ Departamento de Agricultura (DAG), Universidade Federal de Lavras (UFLA), Lavras, MG, Brasil.

ABSTRACT: Assessing sugarcane (Saccharum spp.) stalk growth helps to adequately manage the phenological stages of the crop. The aim of this study was to describe the height-growth curve of four sugarcane varieties (RB92579, RB93509, RB931530 and SP79-1011), in irrigated plant-cane and ratoon cane plantations, using the Logistic and Gompertz nonlinear models, while considering all deviations from assumptions. The model parameters were estimated based on the least squares method using the Gauss-Newton algorithm. To select the most suitable model, nonlinear measures, adjusted coefficient of determination $\left(R^{2}{ }_{\text {ajd }}\right)$, residual standard deviation (RSD), and corrected Akaike information criterion (AICc) were used. Based on the best models, stalk height growth rates and crop phenological stages were determined using critical points. All tests were performed in the free software environment for statistical computing and graphics, $R$. In general, the Logistic and Gompertz models without AR(1) better described the plant-cane and ratoon cane stalk height, respectively. All varieties showed early growth, and the RB92579 variety presented higher rates in both cycles.

Key words: logistic model, gompertz model, growth rates.

Ajuste da curva de crescimento de variedades de cana-de-açúcar utilizando modelos não lineares

RESUMO: A avaliação do crescimento dos colmos de cana-de-açúcar (Saccharum spp.) ajuda a adequar o manejo com as fases fenológicas da cultura. Objetivou-se com este trabalho descrever a curva de crescimento da altura de quatro variedades de cana-de-açúcar (RB92579, RB93509, RB931530 e SP79-1011), nos cultivos de cana planta e cana soca irrigados, utilizando os modelos não lineares Logístico e Gompertz, e considerando eventuais desvios de pressupostos. A estimação dos parâmetros dos modelos foi feita com base no método dos mínimos quadrados utilizando o Algoritmo de Gauss-Newton. Para selecionar o modelo mais adequado foram utilizadas as medidas de não linearidade, o coeficiente de determinação ajustado $\left(R_{a}^{2}\right)$, o desvio padrão residual (DPR) e o critério de informação de Akaike corrigido (AICc). Com base nos melhores modelos foram determinadas as taxas de crescimento da altura dos colmos e as fases fenológicas da cultura por meio dos pontos críticos. Todas as análises foram realizadas no software estatístico R. No geral, os modelos Logistico e Gompertz sem AR(1) descreveram melhor a altura dos colmos em cana planta e cana soca, respectivamente. Todas as variedades apresentaram crescimento precoce, a variedade RB92579 apresentou maiores taxas em ambos os ciclos.

Palavras-chave: modelo logístico, modelo gompertz, taxas de crescimento.

\section{INTRODUCTION}

Sugarcane (Saccharum spp.) is a crop grown in more than 100 countries with tropical and subtropical climates and is particularly important for worldwide agribusinesses. Brazil is the largest sugarcane producer, with 8.59 million hectares and a total production of 620.44 million tons, which is ahead of India, China, and Thailand. Brazilian production is equivalent to $39 \%$ of the total sugarcane produced in the world, and the Central South is the largest Brazilian sugarcane-producing region, with over $92 \%$ of Brazilian sugarcane production, of which the state of São Paulo accounts for 58\% (CONAB, 2019).

This crop generates jobs/income and is the main raw material used in sugarcane, ethanol, 
and cachaça production. The low yield of sugarcane varieties affects the amount of sugarcane derivatives. Thus, studying crop growth and adapting variety management to phenological stages becomes important, particularly for maximizing plant growth, which coincides with periods of increased water availability. Water deficiency, in addition to limiting crop yields, reduces the genetic potential of the crop.

The yield of sugarcane varieties is determined based on the morphophysiological variables of the plant. TOPPA et al. (2010) considered stalk height and diameter as the main variables, thereby conducting studies to understand the dynamics of their growth. According to ARCHONTOULIS \& MIGUEZ (2015), the most widely used standard method is quantitative growth analysis, often performed using multiple linear and polynomial regression models. Plant growth shows a sigmoid pattern: slow at first, undergoing a faster phase, and eventually slowing down again. Therefore, growth should be described using nonlinear models, which have better horizontal asymptotes and fewer parameters. Additionally, nonlinear models provide a better fit than linear models and their estimates may have biological and practical interpretations.

Several authors have used these models to describe plant and fruit growth (MUIANGA et al., 2016; PEREIRA et al., 2016; RIBEIRO et al., 2018a; RIBEIRO et al., 2018b). The most frequently used models for sugarcane are the Logistic and Gompertz models, commonly adjusted for stalk growth (SILVA et al., 2012; BATISTA et al., 2013). Based on these models, plant growth rates can be determined (GAVA et al., 2001; SANTOS et al., 2009; PEDULA et al., 2016), indicating increase in growth over time. These rates help determined the duration of the phenological stages, model curve inflection point (IP), points of maximum acceleration (PMA), minimum deceleration point (PMD), and asymptotic deceleration (PDA). According to OLIVEIRA et al. (2010), the IP is highly important for sugarcane because it indicates the date when the greatest plant growth has been achieved and from when growth starts to increase at decreasing rates until nearing zero, indicating that the plant is already in the maturation phase. According to MISCHAN et al. (2011), the PDA and PMD indicate the end of the slow and exponential growth phases; respectively, whereas the PDA indicated growth stabilization.

According to MUIANGA et al. (2016) and RIBEIRO et al. (2018b), the nonlinear model parameters are not estimated based on the least squares method. However, because the system of equations has no explicit solution, iterative methods are used to obtain the estimates, most commonly the Gauss-Newton algorithm. According to these authors, once the model parameters are estimated, the residuals are analyzed, usually applying the ShapiroWilk, Durbin-Watson, and Breush-Pagan tests, which assessed the assumptions of normality, independence of residuals, and variance homogeneity, respectively. When assessing the failure to fulfill an assumption, weighted or generalized least squares methods are used to estimate the parameters (MUNIZ et al., 2017). Through nonlinear measures, the nonlinear behavior of the models are evaluated and their adjustment was evaluated based on quality evaluators, with the determination coefficient, residual standard deviation, and Akaike information criterion being the most cited.

Thus, this study aimed to describe the sugarcane stalk height growth curve, for the RB92579, RB93509, RB931530, and SP79-1011 varieties, in plant-cane and ratoon cane cycles, using the Logistic and Gompertz nonlinear models, considering any deviations from assumptions.

\section{MATERIALS AND METHODS}

The analyzed data was derived from an experiment conducted in the experimental Agrometeorology area of the Center for Agricultural Sciences (Centro de Ciências Agrárias), Federal University of Alagoas (Universidade Federal de Alagoas - UFAL), Delza Gitaí Campus, Rio Largo, in the Coastal Tablelands of Alagoas (ALMEIDA et al., 2008). The experiment was conducted using the randomized block design, with five replicates and four treatments, including the RB92579, RB93509, RB931530, and SP79-1011 varieties, in plantcane and ratoon cane crop cycles. The soil of the experimental area was classified as cohesive argisolic Yellow Latosol of a medium/clayey texture, with mild topography and a slope lower than $2 \%$. The varieties were planted in October 2003 within row spacings of $1.25 \mathrm{~m}$, in $4 \mathrm{~m}$ plots with 5 furrows, corresponding to $25 \mathrm{~m}^{2}$ per plot and a total area of $500 \mathrm{~m}^{2}$. Two $\mathrm{t}$ $\mathrm{ha}^{-1}$ of dolomitic limestone (PRNT $=85 \%$ ) was added, with 70,60 , and $120 \mathrm{~kg} \mathrm{ha}^{-1}$ of $\mathrm{N}, \mathrm{P}_{2} \mathrm{O}_{5}$, and $\mathrm{K}_{2} \mathrm{O}$ base fertilization, respectively.

The plants were irrigated during the first plant growth stages (from sprouting to tillering), based on crop evapotranspiration (ETc) data. In this study, 17 plant-cane and ratoon cane stalk height measurements were taken 30 days after planting (DAP) and after cutting (DAC) for 360 days. The interval between observations was 15 days until the plants completed half of the growth cycle and 30 days in the final 180 DAP and DAC. All plants in the 
central row of each plot were evaluated, measuring the stalks from the soil to the insertion of the first fully developed leaf $($ leaf +1$)$ with a visible auricle.

The Logistic and Gompertz nonlinear models were evaluated according to the parameterization suggested by FERNANDES et al. (2015). These models are represented by the following equations: $Y_{i}=A /\left(1+\exp \left(i\left(B-x_{i}\right)\right)\right)+\varepsilon_{i}$ and $\left.Y_{i}=A \exp \left(-\exp k\left(B-x_{i}\right)\right)\right)+\varepsilon_{i}$ respectively. For both models, $Y_{i}$ represents the observed height (m) values in observations $i=1, \ldots, 17$; $A$ represents the maximum horizontal asymptote, that is, the maximum stalk height to be reached; $k$ represents the growth rate (the higher $k$ is, the faster the plants will reach $A$ ); and $B$ is interpreted as the abscissa of the inflection point of the Logistic model, from which growth slows down. The inflection point occurs at $50 \%$ of the horizontal asymptote $(0.5 \mathrm{~A})$ in the Logistic model and $37 \%$ in the Gompertz model $(0.37 A) . \varepsilon_{i}$ corresponds to the random error, which is assumed to be independently and identically distributed following a normal distribution with a mean of zero and constant variance, that is, $\varepsilon \sim N\left(0, \sigma^{2}\right)$.

The graphical analysis of the residuals as a function of time (DAP and DAC) was performed, indicating the order ( $p)$ of the autocorrelation parameters (AR) through the partial autocorrelation function. When assessing the correlation between observations, the parameters were estimated using the generalized least squares method, incorporating $\mathrm{AR}(\mathrm{p})$ into the residuals. Thus, the residual value is provided using $\varepsilon_{t}=\phi_{1} \varepsilon_{t-1}+\ldots+\phi_{p} \varepsilon_{t-p}+e_{t}$. Wherein, $\mathcal{E}_{t}$ and $\mathcal{E}_{t-1}$ are the residuals at times $\mathrm{t}=1,2 \ldots \mathrm{p}$ and $\mathrm{t}$-p, respectively; $\phi_{1}$ is the autocorrelation parameter of order 1 ; while $e_{\text {is }}$ is the white noise, that $\mathrm{i} e_{t} \sim N\left(0 ; \sigma_{\mathrm{e}}^{2}\right)$ being, $E\left(e_{t}\right)=0, E\left(e_{t}^{2}\right)=\sigma_{\mathrm{e}}^{2}$, and, $E\left(e_{t} ; e_{\mathrm{t}-\mathrm{h}}\right)=0$ for $h \neq 0 \quad$ (MORETTIN \& TOLOI, 2006). Subsequently, Shapiro-Wilk, Breusch-Pagan, and Durbin-Watson tests were used to validate the nonviolation of the assumptions of normality, variance homogeneity, and independence of residuals.

The best model was selected using intrinsic nonlinear measures (IN) and the parametric effect (PE), assessed with the rms.curv( ) function of the $\mathrm{R}$ software ( $\mathrm{R}$ CORE TEAM, 2018). Nonlinearity is used to indicate how distant a nonlinear model is from a linear model (FERNANDES et al., 2015). The quality of the model fit was assessed based on the adjusted coefficient of determination $R_{a j j}^{2}=1-\left[\left(1-R^{2}\right)(n-i)\right] /(n-p)$, residual standard deviation: $\quad R S D=\sqrt{S S R /(n-p)}$, and corrected Akaike Information Criterion: $A I C c=$ $n \operatorname{In}(S S R / n)+[2 p(p+1)] /(n-p-1)$. Wherein, $S S R$ and SST are the sum of the squared residuals and total square sum, respectively; $n$ is the number of observations; $p$ is the number of adjusted model parameters; $i$ is related to the fit of the intercept to the curve, which is 1 if there is an intercept and 0 otherwise. $R^{2}=1-(S S R / S S T)$ is the coefficient of determination, which indicates the variation of the data explained by the model, whereas $R_{a d j}^{2}$ is only used to selected the models. The most suitable model is that with the highest $R_{a d j}^{2}$ and lowest $A I C c$ values, evaluated using the Rsq.ad() and $A I C c$ () functions of the R software, respectively.

The model parameters were estimated based on the least squares method, using the GaussNewton algorithm, based on the Taylor series expansion, and implemented in the $n l s$ ( ) function of the R software. Stalk growth rates (SGR) were determined through the first derivative of the best growth over time (DAP or DAC) for each variety. The first derivatives of the Logistic and Gompertz models are provided by $y=\mathrm{A} k \exp \left(k\left(\mathrm{~B}-x_{i}\right)\right) /((1$ $\left.\left.+\exp \left(B-x_{i}\right)\right)\right)^{2}$ and, $\mathrm{y}=A \operatorname{Akexp}(-\exp (\mathrm{k}(\mathrm{B}-\mathrm{x})))$ $\exp (\mathrm{k}(\mathrm{B}-\mathrm{x}))$ respectively. The coordinates of the points of maximum acceleration (PMA), minimum deceleration (PMD), and asymptotic deceleration (PDA) of stalk growth were also calculated using the second, third, and fourth derivatives in relation to the independent variable (time), respectively. Based on the Logistic model, the PMA, PMD, and PDA coordinates are obtained by: $x_{P, Q 4}=(-\ln (2+\sqrt{3})-k B) / k$, $y_{P M A}=A /(3+\sqrt{3}), \quad x_{P M D}=(-\ln (2-\sqrt{3})-k B) / k$, $y_{P, D}=A /(3-\sqrt{3})$ and $x_{P D A}=(-\ln (5-2 \sqrt{6})-k B) / k$, $y_{P D A}=A /(2(3-\sqrt{6})) \quad$ respectively. Conversely, the Gompertz model is used to determine: $x_{P, L A}=(-\ln ((3+\sqrt{5}) / 2)+k B) / k$ $y_{P M A}=A \exp (-((3+\sqrt{5}) / 2)) ; x_{P M D}=(-\ln ((3-\sqrt{5}) / 2)+k B) / k$, $\left.y_{P M D}=A \exp (-(3-\sqrt{5}) / 2)\right)$ and $x_{P D A}=(-\ln (0,165758)-k B) / k$, $y_{P D A}=A \exp (-0,165758)$, respectively (MISCHAN et al., 2011; KLEINPAUL et al., 2018). The significance of the model parameters was assessed using the lackof-fit (F) test at the $1 \%$ significance level.

\section{RESULTS AND DISCUSSION}

Figure 1 shows the graphs concerning the analysis of the residuals of the Logistic and Gompertz models adjusted to the average stalk height of plant-cane and ratoon cane. The trend in the Gompertz model, as shown in figure 1 (e, f, g, and $\mathrm{h}$ ) in the plant-cane cycle, indicated residual autocorrelation. Several authors have also observed residual autocorrelation in growth studies, including PEREIRA et al. (2014), MUIANGA et al. (2016), and MUNIZ et al. (2017) when evaluating the height of coffee plants, cashew nuts, and cocoa beans, 


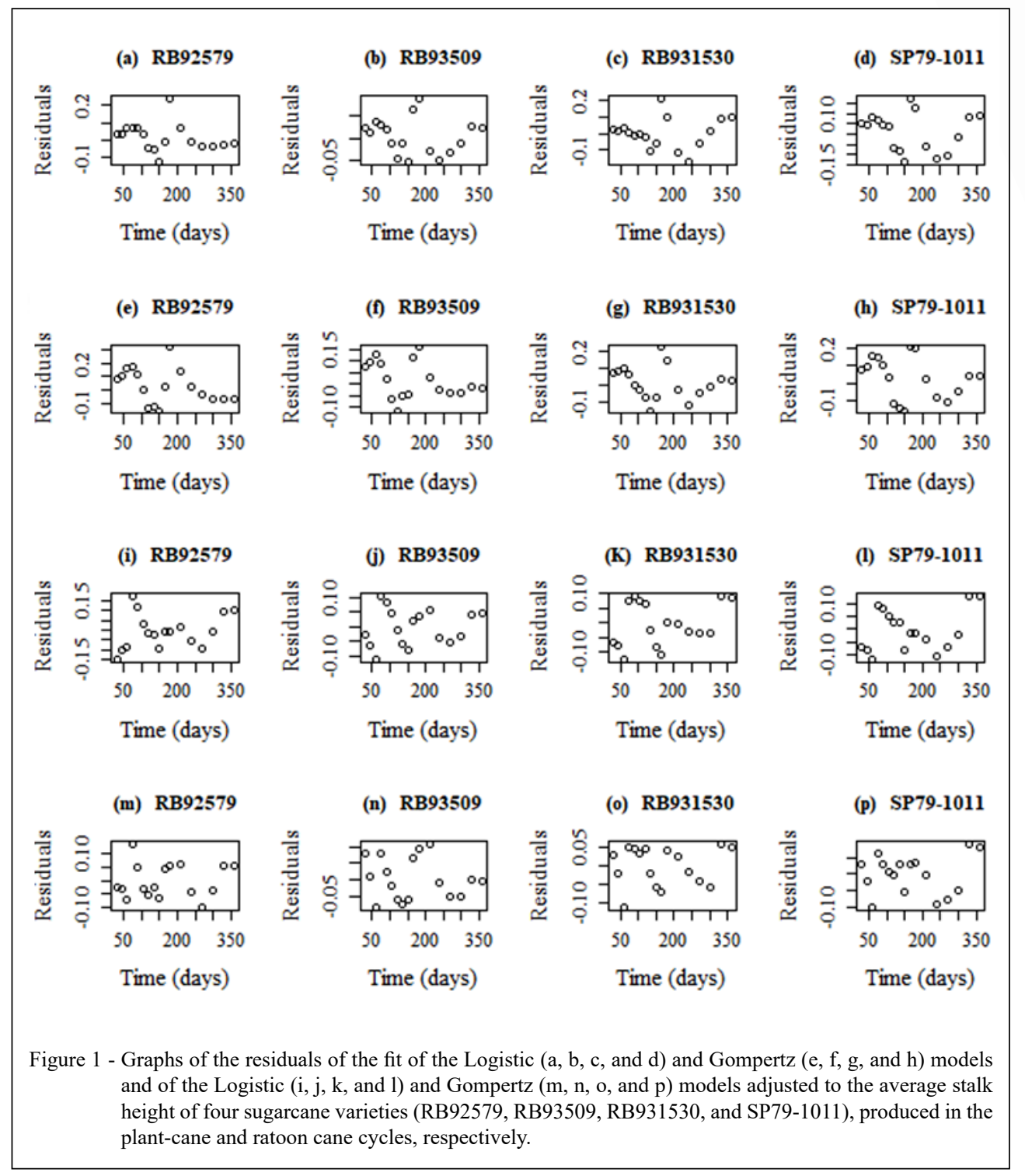

respectively. The failure to fulfill the assumption of the independence of the residuals (autocorrelation) primarily occurs when the measurements are taken from the same individual over time.

The autocorrelation function of the residuals also indicated residual dependence for the Gompertz model when adjusted to plant-cane stalk height data (Figure 2; e, f, g, and h). As lags 1 and 2 were significant, second-order autocorrelation was modeled. However, the $\mathrm{F}$ test indicated the non-significance of the $\phi$ parameter, which showed a confidence interval with the value zero. Thus, to ensure a greater accuracy of estimates, the first-order autoregressive parameter AR(1) was added. Table 1 outlines the results from the analysis of the assumptions of the normality of the residuals, variance homogeneity, and independence of the residuals assessed using the Shapiro-Wilk (SW), Breusch-Pagan (BP), and Durbin-Watson (DW) tests, respectively, at the $1 \%$ significance level. All assumptions were fulfilled, indicating that the estimates obtained are reliable and the inferences are valid.

Table 1 also outlines the values for the assessment of the intrinsic nonlinear measures (IN) and parametric effects (PE). Neither the intrinsic nonlinearity nor parametric effect were significant in either model (Logistic and Gompertz), in the four varieties and both cycles of cultivation. According to FERNANDES et al. (2015), the values of these 


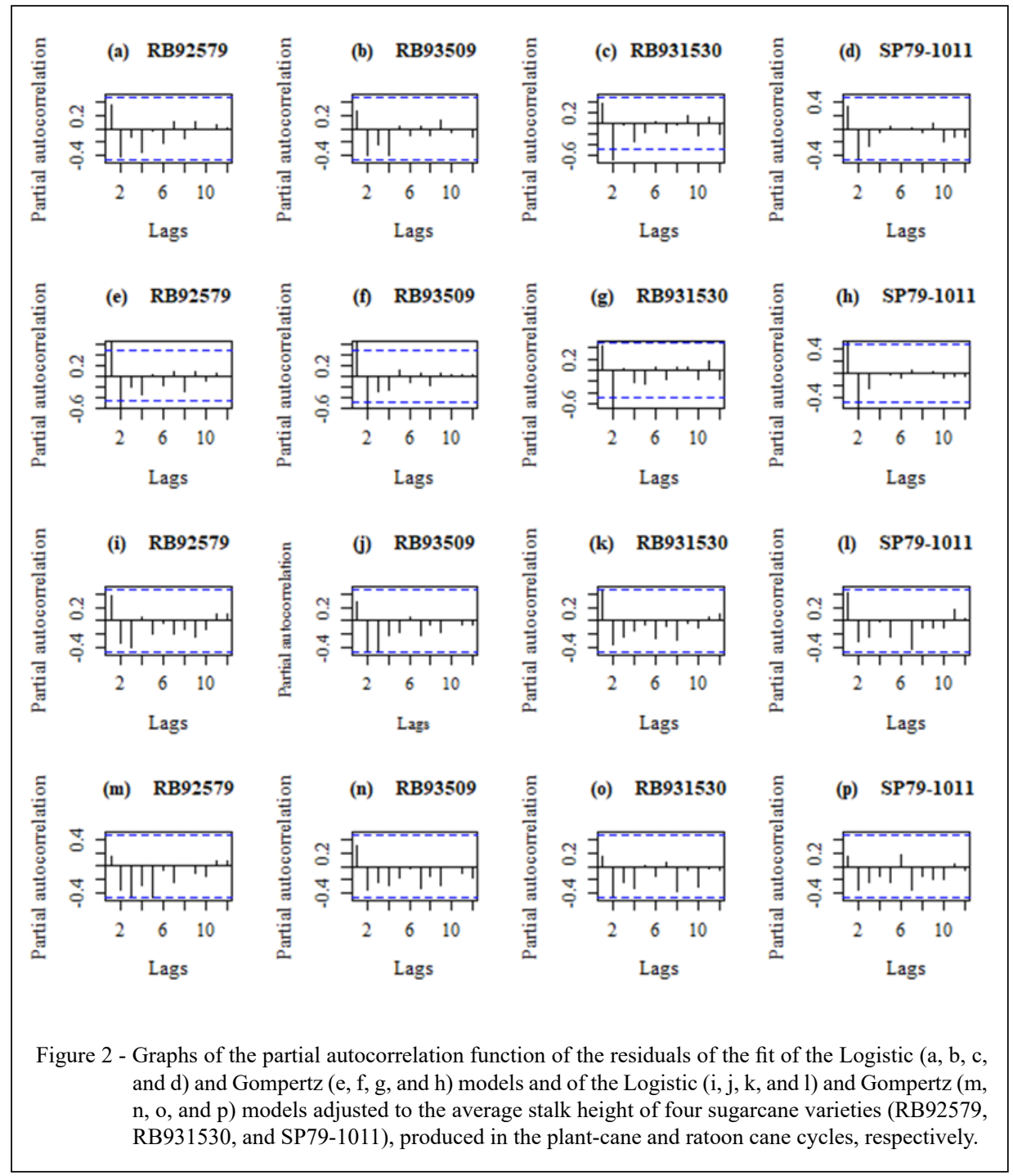

measures are significant when higher than 0.5 , thus indicating deviation from the linearity of the adjusted models. In this study, the Logistic model presented the lower values for the two measures in plant-cane, whereas the Gompertz model, concerning ratoon cane, presented lower values in three varieties (RB92579, RB931530, and SP79-1011). Thus, these models are close to the linear model, which ensures a greater reliability of their estimates.

The fit quality evaluators, outlined in Table 1 , also indicated higher $R_{a d j}^{2}$ values and lower $R S D$ and $A I C c$ values of the Logistic model in plant-cane. The sugarcane crop requires proper management during the first growth stage, especially in the plantcane cycle. According to OLIVEIRA et al. (2010), at first, plant-cane tillers grow slowly because they rely on the adaption of the seed piece reserves. Therefore, the Logistic model is perfectly suited to describe its growth, corroborating the results from this study. The Logistic model can capture longer sprouting and tillering stages because its inflection point is reported at the midpoint of the asymptote $(0.5 A)$. MUIANGA et al. (2016), PEREIRA et al. (2016), MUNIZ et al. (2017), and RIBEIRO et al. (2018b) also reported better fits in the Logistic model than in the Gompertz model when studying cashew nut and cacao bean growth, coffee canopy diameter, and pears, respectively.

For the ratoon cane cycle, the Gompertz model showed higher $R_{a d j}^{2}$ values and lower $R S D$ and $A I C C$ values in three varieties (RB92579, 
Table 1 - P-values for the Shapiro-Wilk (SW), Breusch-Pagan (BP), and Durbin-Watson (DW) tests, intrinsic nonlinearity (IN), parametric effect (PE), adjusted coefficient of determination $\left(R_{a d j}^{2}\right)$, residual standard deviation (RSD), and corrected Akaike information criterion (AICc) of the Logistic and Gompertz models adjusted to the average stalk height of four sugarcane varieties (RB92579, RB93509, RB931530, and SP79-1011), produced in the plant-cane and ratoon cane cycles.

\begin{tabular}{|c|c|c|c|c|c|c|c|c|c|}
\hline Models & Varieties & SW & $\mathrm{BP}$ & DW & IN & PE & $R_{a d j}^{2}$ & RSD & $\mathrm{AICc}$ \\
\hline ------------- & & - & 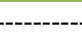 & Plant-c & -2 & --------- & -------- & -------- & ------------ \\
\hline \multirow{4}{*}{ Logistic } & RB92579 & 0.053 & 0.087 & 0.040 & 0.056 & 0.106 & 0.994 & 0.087 & -28.087 \\
\hline & RB93509 & 0.583 & 0.020 & 0.048 & 0.032 & 0.062 & 0.998 & 0.044 & -51.511 \\
\hline & RB931530 & 0.886 & 0.026 & 0.020 & 0.074 & 0.162 & 0.987 & 0.097 & -24.520 \\
\hline & SP79-1011 & 0.169 & 0.013 & 0.020 & 0.077 & 0.143 & 0.992 & 0.089 & -27.653 \\
\hline \multirow{4}{*}{ Gompertz $^{1}$} & RB92579 & 0.605 & 0.779 & 0.076 & 0.115 & 0.212 & 0.984 & 0.114 & -17.998 \\
\hline & RB93509 & 0.067 & 0.472 & 0.244 & 0.081 & 0.152 & 0.991 & 0.089 & -35.623 \\
\hline & RB931530 & 0.999 & 0.070 & 0.650 & 0.099 & 0.250 & 0.986 & 0.104 & -23.498 \\
\hline & SP79-1011 & 0.018 & 0.808 & 0.290 & 0.124 & 0.238 & 0.981 & 0.140 & -15.819 \\
\hline & --------------- & --------- & -------- & Ratoon & ------ & -1---- & ----- & ----- & ----------- \\
\hline \multirow{4}{*}{ Logistic } & RB92579 & 0.659 & 0.015 & 0.886 & 0.046 & 0.110 & 0.989 & 0.093 & -26.043 \\
\hline & RB93509 & 0.774 & 0.549 & 0.046 & 0.035 & 0.084 & 0.994 & 0.065 & -38.066 \\
\hline & RB931530 & 0.091 & 0.159 & 0.046 & 0.052 & 0.123 & 0.985 & 0.080 & -31.312 \\
\hline & SP79-1011 & 0.312 & 0.443 & 0.082 & 0.051 & 0.123 & 0.986 & 0.086 & -28.716 \\
\hline \multirow{4}{*}{ Gompertz } & RB92579 & 0.165 & 0.732 & 0.118 & 0.031 & 0.099 & 0.995 & 0.067 & -37.051 \\
\hline & RB93509 & 0.193 & 0.456 & 0.044 & 0.036 & 0.115 & 0.994 & 0.068 & -36.638 \\
\hline & RB931530 & 0.046 & 0.527 & 0.184 & 0.034 & 0.109 & 0.993 & 0.056 & -43.190 \\
\hline & SP79-1011 & 0.497 & 0.069 & 0.126 & 0.035 & 0.116 & 0.993 & 0.063 & -39.460 \\
\hline
\end{tabular}

${ }^{1}$ model with AR(1) errors

RB931530, and SP79-1011), corroborating the results of the nonlinear measures. Ratoon cane usually grows fast by using the seed piece reserve after the stalks have been cut, thus shortening phenological stages. Therefore, the Gompertz model describes ratoon cane growth better than the Logistic model, because the inflection point of the former precedes that of the latter. Curiously, the RB93509 variety presented better nonlinear measure and fit evaluator results in the Logistic model. This indicated that the variety grew slowly, perhaps due to water stress and soil compaction as a result of mechanized harvesting. These factors strongly affect ratoon sprouting and tiller growth. In the literature, some authors have also reported good fits of the Gompertz model when evaluating ratoon cane growth, such as BATISTA et al. (2013), who studied the varieties RB92579, RB867515, RB928064, and RB855453 during the crop development period.

Thus, the Logistic model was selected as the best model to describe plant-cane growth. Whereas, the Gompertz model was selected for the ratoon cane varieties RB92579, RB931530, and
SP79-1011, while the Logistic model was selected for the ratoon cane variety RB93509. The analysis of the parameter estimates of the selected models shows that in both plant-cane and ratoon cane, the RB92579 variety had the highest $A$ and $k$ values (Table 2), followed by SP79-1011. The results also showed that the higher the $k$ value is, the lower the $B$ estimate will be, indicating that the variety grows fast and it takes less time to reach the maximum growth rate. The inflection points of the growth curves occurred approximately from 129 to 146 DAP in plant-cane and from 79 to $90 \mathrm{DAC}$ in ratoon cane. All estimated parameters were significant according to the $t$ test at the $1 \%$ significance level, thus rejecting the hypothesis that model parameter estimates are zero.

The results of the plant-cane estimates are similar to those observed by FREITAS et al. (2012) when analyzing irrigated sugarcane growth. These authors assessed average stalk height values ranging from 2.435 to $2.743 \mathrm{~m}$. SANTOS et al. (2009) reported results close to the estimates of the RB93509 and SP79-1011 varieties when assessing the growth of the RB75126 variety, with the average stalk height 
Table 2 - Estimates of the parameters (A, B, and k), standard error of the estimate in parentheses, and autoregressive parameters $\left(\phi_{1}\right)$ of the Logistic and Gompertz models adjusted to the average stalk height $(\mathrm{m})$ of four sugarcane varieties (RB92579, RB93509, RB931530, and SP79-1011), produced in the plant-cane and ratoon cane cycles.

\begin{tabular}{|c|c|c|c|c|c|}
\hline \multirow[t]{2}{*}{ Models } & \multirow[t]{2}{*}{ Varieties } & \multicolumn{4}{|c|}{--Estimates of the parameters --- } \\
\hline & & A & $\mathrm{B}$ & $\mathrm{k}$ & $\phi_{1}$ \\
\hline \multirow{4}{*}{ Logistic } & RB92579 & $2.685(0.039)$ & 136.491 (1.919) & $0.039(0.002)$ & \\
\hline & RB93509 & $2.266(0.019)$ & 128.913 (1.159) & $0.037(0.001)$ & \\
\hline & RB931530 & $2.166(0.049)$ & $145.670(3.281)$ & $0.031(0.003)$ & \\
\hline & SP79-1011 & $2.319(0.045)$ & $143.597(2.550)$ & $0.038(0.003)$ & \\
\hline \multirow{4}{*}{ Gompertz $^{1}$} & RB92579 & $2.711(0.114)$ & $121.752(4.857)$ & $0.026(0.004)$ & 0.634 \\
\hline & RB93509 & $2.300(0.074)$ & $114.051(3.806)$ & $0.025(0.003)$ & 0.683 \\
\hline & RB931530 & $2.262(0.093)$ & $127.230(5.076)$ & $0.019(0.003)$ & 0.441 \\
\hline & SP79-1011 & $2.336(0.107)$ & $128.017(5.240)$ & $0.026(0.005)$ & 0.549 \\
\hline \multirow{4}{*}{ Logistic } & RB92579 & $2.813(0.043)$ & $101.700(2.458)$ & $0.027(0.002)$ & \\
\hline & RB93509 & $2.566(0.031)$ & 111.800 (1.937) & $0.027(0.001)$ & \\
\hline & RB931530 & $2.113(0.036)$ & $100.400(2.782)$ & $0.027(0.002)$ & \\
\hline & SP79-1011 & $2.275(0.040)$ & $104.300(2.829)$ & $0.027(0.002)$ & \\
\hline \multirow{4}{*}{ Gompertz } & RB92579 & $2.874(0.036)$ & $80.199(1.626)$ & $0.019(0.001)$ & \\
\hline & RB93509 & $2.636(0.039)$ & $89.671(1.881)$ & $0.018(0.001)$ & \\
\hline & RB931530 & $2.160(0.029)$ & 79.395 (1.789) & $0.019(0.001)$ & \\
\hline & SP79-1011 & $2.334(0.034)$ & $82.920(1.907)$ & $0.018(0.001)$ & \\
\hline
\end{tabular}

${ }^{1}$ model with $\mathrm{AR}(1)$ errors.

ranging from 2.312 to $2.420 \mathrm{~m}$. COSTA et al. (2011) conducted the same experiment in the fourth crop cycle ( $3^{\text {rd }}$ ratoon), and reported results similar to the findings of the present study ( $2^{\text {nd }}$ ratoon) using the Gompertz model. The authors obtained estimates of 2.750 and $2.381 \mathrm{~m}$ for the asymptotic parameter of the RB92579 and SP79-1011 varieties, respectively. According to SILVA et al. (2012), the RB92579 variety showed higher shoot growth and is one of the varieties with the highest dry mass production, especially in ratoon cane, using soil nutrient reserves after the stalks of the previous cycle are cut.

The graphs concerning the fit of the best models are shown in figures $3 \mathrm{~A}$ and $3 \mathrm{C}$ for plant-cane and ratoon cane, respectively. The growth of each variety is explained by figures $3 \mathrm{~B}$ and $3 \mathrm{D}$, which showed the stalk growth rates (SGR) of the four varieties. In these figures, the highest SGR indicated the inflection point (IP) of the model curve, which coincides with the estimate of parameter $B$, according to the variety and respective model. In plant-cane, the IP of the RB93509, RB92579, SP79-1011 and RB931530 varieties occurred when they showed an SGR of 2.096, 2.201, 2.618, and $1.678 \mathrm{~cm}^{-1 a y}{ }^{-1}$ (Figure 3B), respectively. According to the parameter $B$ estimates (129 to 146 DAP), the IP occurred in February for the first three varieties, and in March for the last, thus coinciding with the rainy season in the Northeast region.

Conversely, in ratoon cane, the IP (from 79 to 83 DAC) occurred in December when the RB92579, RB931530, and SP79-1011 varieties reached an SGR of 2.009, 1.510, and $1.546 \mathrm{~cm} \mathrm{day}^{1}$ (Figure 3D), respectively. COSTA et al. (2011) 


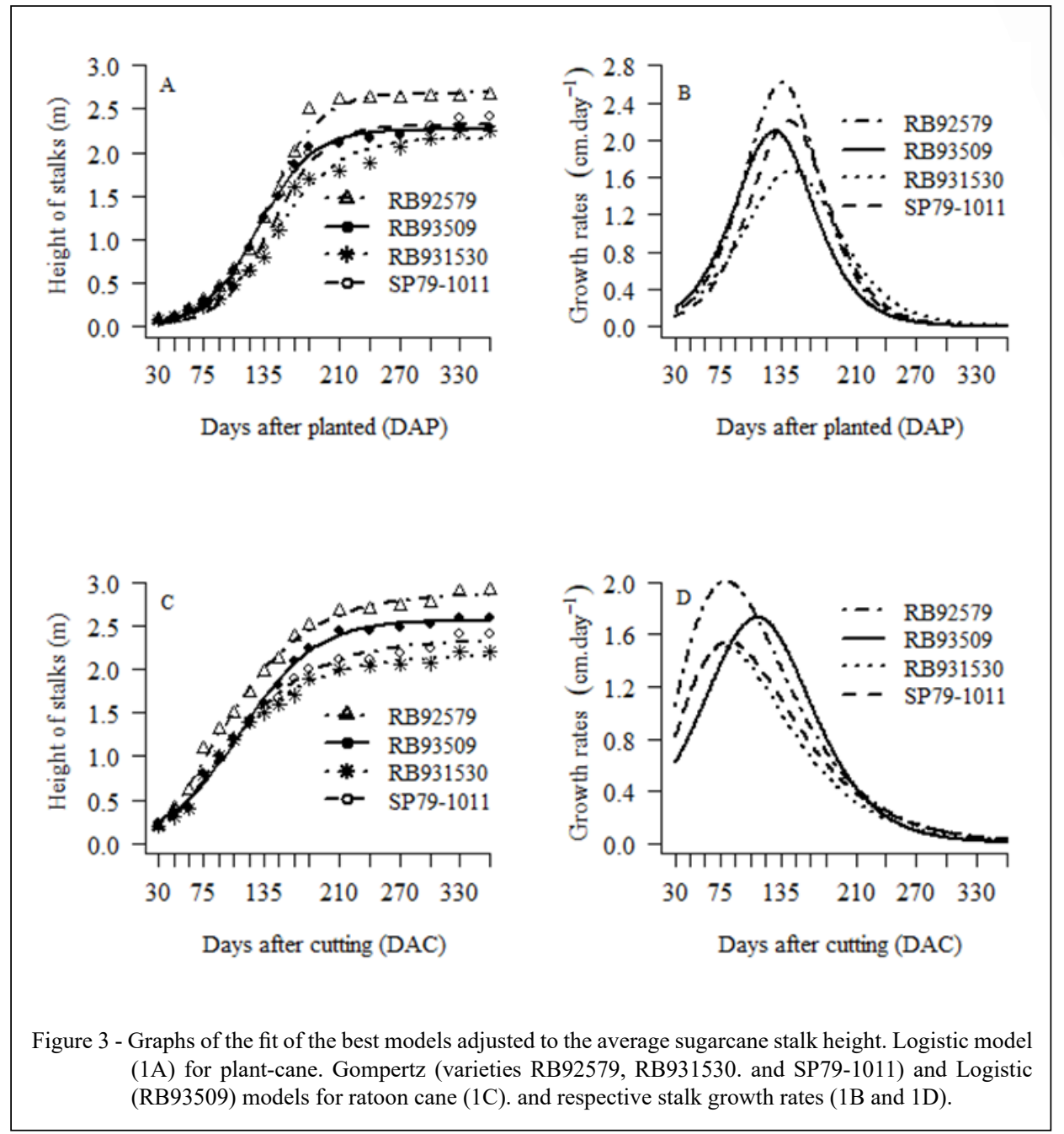

also observed low SGR values in relation to the IP: $1.210,0.900$, and $0.800 \mathrm{~cm} \mathrm{day}^{-1}$ in the RB92579, RB931530, and SP79-1011 varieties, respectively. SILVA et al. (2012) observed low SGR in the IP of the height increase of the irrigated RB92579 variety, approximately $1.837 \mathrm{~cm} \mathrm{day}^{-1}$, at $218 \mathrm{DAC}$ in the first ratoon cane cycle in the Sub-middle São Francisco Valley, Bahia State. The low rates may have been caused by the fact that with each sugarcane cut the regrowth capacity of the sugarcane decreases, due to factors such as soil compaction, variety characteristics, and edaphoclimatic conditions.

According to critical point estimates, three stalk growth stages were identified. Plant-cane PMA estimates indicated that the first stage (from sprouting to tillering) ended from approximately 93 to 103 DAP, when the stalks showed $21 \%$ of the asymptote $(A)$ in the four study varieties. The vegetative growth phase ended approximately between 165 and 188 DAP, as determined by the PMD, with $79 \%$ of the asymptotic parameter estimate. Conversely, growth stabilization (PDA) started from 190 to 220 DAP, with $91 \%$ of the $A$ estimate, indicating the asymptotic deceleration point (PDA). When stalk growth reaches the PDA, crop management should be restricted to promote sucrose accumulation over vegetative growth, as reported by OLIVEIRA et al. (2010), SILVA et al. (2012), and BATISTA et al. (2013).

The critical points assessed using the Gompertz model in three varieties (RB92579, RB931530, and SP79-1011) indicated that the first stalk growth stage ended on the first month (from 29 to $30 \mathrm{DAC})$, whereas the second stage ended from 130 to 136 DAC, with a stalk height of 7 and $68 \%$, 
respectively. Conversely, at $85 \%$ height, the growth of these varieties began to stabilize, from 175 to 183 DAC. These results indicated small differences between the PMA, PDM, and PDA estimates in the ratoon cane cycle, most likely because ratoon cane is more easily managed than plant-cane.

At the maturation stage, the vegetative growth of sugarcane stalks decreases. The results of the critical point estimates indicated that sugarcane maturation accounted for approximately 21 and 32\% of plant-cane and ratoon cane stalk height growth, respectively. Ratoon cane grows very fast, closing the inter rows very early on. Thus, weeds are suffocated, thereby reducing moisture losses during the first two stalk growth stages.

\section{CONCLUSION}

The four study varieties showed growth with a sigmoid pattern in both crops. In general, the Logistic and Gompertz models without AR(1) better described the data of the mean sugarcane stalk height. The Logistic model was better suited to describe the plant-cane growth curve, whereas the Gompertz model better described the growth of the three varieties in the ratoon cane cycle.

The maximum stalk height growth rates occurred from 129 to 146 DAP and from 79 to 90 DAC, when the stalks reached from 1.678 to 2.618 $\mathrm{cm}$ day $^{-1}$ and from 1.510 to $2.009 \mathrm{~cm} \mathrm{day}^{-1}$ for plantcane and ratoon cane, respectively.

\section{ACKNOWLEDGMENTS}

To the Mozambique Scholarship Institute (Instituto de Bolsas de Estudo de Moçambique - IBE), Coordination for the Improvement of Higher Education Personnel (Coordenação de Aperfeiçoamento de Pessoal de Nível Superior - CAPES), and National Council for Scientific and Technological Development (Conselho Nacional de Desenvolvimento Científico e Tecnológico $-\mathrm{CNPq}$ ) for the scholarships granted to the first, second, and third authors, respectively.

\section{DECLARATION OF CONFLICT OF INTERESTS}

The authors declare no conflict of interest. The founding sponsors had no role in the design of the study; in the collection, analyses, or interpretation of data; in the writing of the manuscript; and in the decision to publish the results.

\section{AUTHORS' CONTRIBUTIONS}

All authors contributed equally for the conception and writing of the manuscript. All authors critically revised the manuscript and approved of the final version.

\section{REFERENCES}

ALMEIDA, A. C. dos S. et al. Vegetative development and production of sugarcane varieties as a function of water availability and thermic units. Ciência e Agrotecnologia, v.32, n.5, p.1441-1448. 2008. Available from: $<$ http://www.scielo.br/scielo.php?pid=S1413$70542008000500013 \&$ script $=\mathrm{sci}$ arttext $\&$ tlng $=\mathrm{es}>$. Acessed: May, 26, 2019. doi: 10.1590/S1413-70542008000500013.

ARCHONTOULIS, S. V; MIGUEZ, F. E. Nonlinear regression models and applications in agricultural research. Agronomy Journal, v.107, n.2, p.786-798. 2015. Available from: <https:// dl.sciencesocieties.org/publications/aj/abstracts/107/2/786>. Accessed: Feb. 10, 2019. doi: 10.2134/agronj2012.0506.

BATISTA, E. L. da S. et al.Modeling of growth of sugarcane cultivars duringthe crop formation period. Revista Brasileira de Engenharia Agrícola e Ambiental, v.17, n.10, p.1080-1087. 2013. Available from: $<$ http://www.scielo.br/scielo.php?pid=S141543662013001000009\&script $=$ sci arttext $>$. Acessed: May, 26, 2019. doi: $10.1590 /$ S1415-436620 13001000009 .

CONAB (COMPANHIA NACIONAL DE ABASTECIMENTO). Acompanhamento da safra brasileira: cana-de-açúcar, segundo levantamento - safra 2018-2019. 2019. Available from: $<$ https://www.conab.gov.br/info-agro/safras/cana/boletim-dasafra-de-cana-de-acucar>. Acessed: Mar. 9, 2019.

COSTA, C. T. S. et al. Growth and yield of four varieties of sugarcane in the third ratoon. Revista Caatinga, v.24, n. 3, p.56-63. 2011. Available from: <http://www.redalyc.org/articulo. oa? $\mathrm{id}=237119874008>$. Acessed: May, 9, 2019.

FERNANDES, T. J. et al.Parameterization effects in nonlinear models to describe growth curves. Acta Scientiarum. Technology, v.37, n.4, p.397-402. 2015. Available from: $<$ http://periodicos.uem. br/ojs/index.php/ActaSciTechnol/article/view/27855>. Accessed: May, 13, 2019. doi: 10.4025/actascitechnol.v37i4.27855.

FREITAS, C. A. S. de et al.Vegetative growth of sugar cane (Saccharum officinarum L.) irrigated with water from treated domestic sewage. Conexões-Ciência e Tecnologia, v.6, n.1, p.27-43. 2012. Available from: $<$ http://conexoes.ifce.edu.br/index. php/conexoes/article/view/456>. Accessed: May, 24, 2019. doi: 10.21439/conexoes.v6i1.456.

GAVA, G. J. de C. et al. Growth and accumulation of nitrogen by sugarcane cultivated in soil covered with cane trash.Pesquisa Agropecuária Brasileira, v.36, n.11, p.1347-1354. 2001. Available from: <http://www.scielo.br/scielo.php?pid=S0100204X2001001100004\&script $=$ sci_arttext\&tlng=pt $>$. Accessed: May, 23, 2019. doi: 10.1590/S0100-204X2001001100004.

KLEINPAUL, J. A. et al. Nonlinear Models for Plant Height of Rye Cultivars at Sowing Times. Journal of Agricultural Science, v.10, n.12, p.157-170. 2018. Available from: $<$ http://www.ccsenet. org/journal/index.php/jas/article/download/0/0/37368/37661>. Accessed: Jun. 6, 2019. doi: 10.5539/jas.v10n12p157.

MISCHAN, M. M. et al. Determination of a point sufficiently close to the asymptote in nonlinear growth functions. Scientia Agricola, v.68, n.1, p.109-114. 2011. Available from: <http://www.scielo. br/scielo.php?pid=S0103-90162011000100016\&script $=\mathrm{sci}$ arttext\&tlng=pt $>$. Accessed: May, 10, 2019. doi: 10.1590/S010390162011000100016 
MORETTIN, P. A.; TOLOI, C. Análise de séries temporais. 2. ed. São Paulo: Blucher, 2006.

MUIANGA, C. A. et al.Description of the growth curve of cashew fruits in nonlinear models. Revista Brasileira de Fruticultura, v.38, n.1, p.22-32. 2016. Available from: <http://www.scielo. br/scielo.php?pid $=$ S0100-29452016000100022\&script $=$ sci abstract\&tlng=pt $>$. Accessed: May, 25, 2019. doi: 10.1590/0100$2945-295 / 14$.

MUNIZ, J. A. et. al. Nonlinear models for description of cacao fruit growth with assumption violations. Revista Caatinga, v.30, n.1, p.250-257. 2017. Available from: <http://www.scielo.br/ scielo.php?script=sci_arttext\&pid=S1983-21252017000100250>. Accessed: May, 13, 2019. doi: 10.1590/1983-21252017v30n128rc.

OLIVEIRA, E. C. A. de et al. Growth and dry matter production in sugarcane varieties grown under full irrigation.Revista Brasileira de Engenharia Agrícola e Ambiental, v.14, n.9, p.951-960. 2010. Available from: <http://www.scielo.br/scielo.php?script=sci_artte xt\&pid=S1415-43662010000900007>. Accessed: Apr. 24, 2019. doi: $10.1590 / \mathrm{S} 1415-43662010000900007$.

PEDULA, R. O. et al.Growth analysis of sugarcane inoculated with diazotrophic bacteria and nitrogen fertilization. African Journal of Agricultural Research, v.11, n.30, p.2786-2795. 2016. Available from: <https://academicjournals.org/journal/ AJAR/article-abstract/4E1ABBB59770>. Accessed: May, 28, 2019. doi: 10.5897/AJAR2016.11141.

PEREIRA, A. A. et al. Description vegetative growth of coffee tree farming ruby MG 1192 using regression models. Coffee Science, v.9, n.2, p.266-274. 2014. Available from: <http://www.sbicafe. ufv.br:80/handle/123456789/8051>. Accessed: Apr. 23, 2019.

PEREIRA, A. A. et al. Modeling of the diameter of the canopy pruned coffee tree cultivated in different densities and water regimes.Lavras: Coffee Science, v.11, n.4, p.495-501. 2016. Available from: <http://www.coffeescience.ufla.br/index.php/
Coffeescience/article/view/1145/pdf_1145>. Accessed: May, 25, 2019. doi: $10.25186 /$ cs.v11i4.1145.

R CORE TEAM. R: A Language and Environment for Statistical Computing. 2018. Available from: <http://www.R-project.org/>. Accessed: Oct. 20, 2018.

RIBEIRO, T. D. et al.Description of the growth of pequi fruits by nonlinear models. Jaboticabal: Revista Brasileira de Fruticultura, v.40, n.4, e-949. 2018a. Available from: <http://www.scielo.br/ scielo.php?script $=$ sci arttext\&pid $=\mathrm{S} 0100-29452018000400705>$. Accessed: May, 13, 2019. doi: 10.1590/0100-29452018949.

RIBEIRO, T. D. et al. The use of the nonlinear models in the growth of pears of 'Shinseiki' cultivar. Santa Maria: Ciência Rural, v.48, n.1, e20161097. 2018b. Availale from: <http://www.scielo.br/ scielo.php?script $=$ sci_arttext\&pid $=\mathrm{S} 0103-84782018000100202>$. Accessed: May, 25, 2019. doi: 10.1590/0103-8478cr20161097.

SANTOS, V. R. dos et al. Growth and yield of sugarcane under different phosphorus sources. Revista Brasileira de Engenharia Agrícola e Ambiental, v.13, n.4, p.389-396. 2009. Available from: $\quad<$ http://www.scielo.br/scielo.php?script=sci_arttext\&pid $=$ S1415-43662009000400004 $>$. Accessed: May, 27, 2019. doi: 10.1590/S1415-43662009000400004.

SILVA, T. G. F. da et al. Biometrics of the sugarcane shoot during irrigated ratoon cycle in the Submedio of the Vale do São Francisco. Revista Ciência Agronômica, v.43, n.3, p.500-509. 2012. Available from: <http://www.scielo.br/scielo.php?pid=S180666902012000300012\&script=sci arttext>. Accessed: May, 27, 2019. doi: $10.1590 / \mathrm{S} 1806-66902012000300012$.

TOPPA, E. V. B. et al. Physiology development in the vegetative stage of sugarcane. Pesquisa Aplicada \& Agrotecnologia, v.3, n.2, p.169-186. 2010. Available from: <https://www.researchgate. net/publication/277820032 Physiology development in the vegetative_stage_of_sugarcane $>$. Accessed: May, 27, 2019. doi: 10.5777/paet.v3i2.1064. 